\title{
Attitude towards 'dowry' among early adulthood, middle and senescence age respondents in urban Jhansi
}

\author{
MEENAKSHI SINGH, POONAM SINGH AND ANJALI SAXENA
}

Received: 03.05.2017; Revised: 04.10.2017; Accepted: 18.10.2017

See end of the paper for authors' affiliations MEENAKSHI SINGH Institute of Home Science, Bundelkhand University, JHANSI (U.P.) INDIA Email : singhmeenu71@gmail. com
ABSTRACT : Present study was conducted in Jhansi city on 100 respondent of three life stages viz., early adulthood-18 to 40 years ( 35 number, 17 male and 18 female), middle adulthood40 to 60 years ( 35 number 18 male 17 female) and senescence-above 60 years ( 30 number, 15 male 15 female) randomly selected from 6 areas to assess their attitude towards dowry by using appropriate scale. Data revealed that almost equal number of respondents belonged to both male and female sex. All the respondents in early adulthood and middle adulthood belonged to Hindu religion, while only $6.7 \%$ of respondents in senescence age were Muslims. More number of male and female respondents in these 3 stages of life span had most unfavourable $\left(\chi^{2}=0.057\right)$ and favourable $\left(\chi^{2}=0.427\right)$, respectively attitude towards dowry. Similarly more number of respondents of Hindu and Muslim religion in senescence stage had most unfavourable and unfavourable attitude towards dowry, while only $20 \%$ and $3.33 \%$ of respondents of Hindu religion had moderate and favorable attitude to dowry. Most of the respondents from all 3 age groups with girls in their family had most unfavourable and unfavourable attitude to dowry, while less number of respondents had favourable attitude to dowry. Early adulthood $\left(\chi^{2}=14.379\right)$ and senescence age $\left(\chi^{2}=10.285^{*}\right)$ group respondents with boys in their families had unfavourable association to dowry.

KEY WORDS: Dowry, Early adulthood, Middle Age, Senescence age (old age)

- HOW TO CITE THIS PAPER : Singh, Meenakshi, Singh, Poonam and Saxena, Anjali (2017). Attitude towards 'dowry' among early adulthood, middle and senescence age respondents in urban Jhansi. Asian J. Home Sci., 12 (2) : 432-436, DOI: 10.15740/HAS/AJHS/12.2/432-436. 